PhDr. Antonín Rašek

Budoucnost bezpečnostního systému ČR

\title{
The Future of Czech Security System
}

\section{Abstrakt:}

Prezentovaná studie vychází metodologicky z práce Martina Potůčka a kol. Poznávání budoucnosti jako výzva. Jeji autor nabízí celkový pohled na několik základních výzev společenských předpovědí. Začíná definováním předvídání jako tvorby základních popisủ možné budoucnosti. Hlavními tématy, jež musíme řěrit, jsou stárnutí populace jako bezpečnostní hrozba, korupce, kriminalita, organizovaný zločin jako faktor politické a ekonomické nestability, marginalizace $A \check{C} R$ v souvislosti s globalizací a evropskou koncepcí obrany, hrozba kolapsu bezpečnostního systému $\check{C} R$.

\section{Abstract:}

Methodically, presented study comes out of a book by Martin Potůček at al. Studying the Future as a Challenge. Its author offers a comprehensive characteristic of several fundamental challenges to social forecasting. It begins by defining forecasting as the formulation of conditional accounts of possible futures. The main forecasting theme to be solved are as follows: ageing Czech population as a security problem, corruption, criminality, organized crime as a tool of political and economy instability, the marginalization of Czech Armed Forces in context of globalization and overall European defence, possible threat of the collapse of Czech defence system.

\section{Klíčová slova:}

Bezpečnostní systém ČR, společenské předpovědi, stárnutí populace, korupce, kriminalita, organizovaný zločin marginalizace AČR, globalizace, evropská koncepce obrany, hrozba kolapsu bezpečnostního systému ČR.

Key words:

Czech Security System, social forecasting, ageing population, corruption, criminality, organized crime, marginalization of ACR, globalization, European defence concept, threat of the collapse of Czech defence system. 
Na internetu kolovala provokativní odpověd' na otázku Potřebujeme současnou armádu? Má však v přeneseném významu jisté pravdivé jádro. Tvrdí, že pokud zrušíme armádu, tak nás prijdou ochránit Italové - nebot zde mají elektrárny, Holand'ané a Dáni - vlastní tu půdu, Francouzi, Němci a Korejci - mají tady automobilky, Američané - ocelárny, Rusové - Karlovy Vary, Rakušané - smetiště, Vietnamci obchody a tržiště, Čínané - jsou nejlepšími zákazníky. No, řkněte - dovolí si někdo, aby ztratil takovou superkolonii?! To nemá žádná země!!!

Základní metodou uplatněnou při formulování variantních možných budoucností České republiky a české společnosti je psaní scénářơ. Výhodou jejího uplatnění je variabilita a sdělnost příběhů, které nabízejí i možnost soustředit se na základní vývojové souvislosti a důsledky uplatnění strategických voleb. Kromě „klasických“ scénářu mohou být zpracovávány i ,divoké karty“, to je náhlé a neočekávané změny poměrů a jejich důsledky. Následující soubor prognóz ale nemá charakter divokých karet, resp. černých labutí, ale je převážně predikcí varující, že pokud bychom pokračovali v některých dosavadních trendech, zejména nedostatečném financování klíčových součástí bezpečnostního systému, mohly by se prognózy do menší či větší míry naplnit.

Soubor scénářůn, kterými se tato studie zabývá, vychází z práce Martina Potůčka Poznávání budoucnosti jako výzva. Mottem Potůčkovy publikace je myšlenka Edwarda Cornishe: „Mnoho lidí se domnívá, že o budoucnosti nemůžeme vědět vůbec nic. Mají z 99,99\% pravdu v doslovném chápání této teze, ale velmi se mýlí v praktickém smyslu. Téměř vše, co nevíme o budoucnosti, nemá pro nás žádný velký praktický význam, ale to málo, co o budoucnosti vědět můžeme, má pro nás význam zcela zásadní, protože nám to může pomoci činit lepší rozhodnutí. Pokud jde o budoucnost, naším úkolem není ji předpovědět - alespoň ne bezchybně - ale zlepšit ji.“

Identifikace bezpečnostních hrozeb a z nich vyplývajících rizik, na nichž je založena tvorba bezpečnostní a vojenské strategie a př́islušných politik, se neobejde bez jejich predikce, bez prognostiky, tvorby prognostických bezpečnostních scénářů i divokých karet, resp. černých labutí, podle knihy Černá labut’ Nassima Nicholase Taleba. [1]

Před současností je podle citované práce mnoho variant možných budoucích stavů světa. Prognostiku charakterizuje neustálá konfrontace dvou typů možných budoucností: „Co by se mohlo stát, pokud bychom za určitých podmínek vykonali toto a toto?“", př́padně „Jaké podmínky je třeba vytvořit a co je třeba rozhodnout a vykonat, aby bylo dosaženo tohoto cíle, resp. čemu se chceme vyhnout?“"Americké pojetí preferuje budoucnosti pravděpodobné, francouzské preferované a české možné.

Arnošt Veselý shrnuje zkušenosti CESES v sedmi bodech, podle něho dobrá prognostická práce: (1) vychází z nejlepších možných empirických fakt, a to jak kvantitativních, tak kvalitativních, (2) rozlišuje normativní a nenormativní rovinu uvažování o budoucnosti, (3) je vnitřně konzistentní, (4) za formulací prognózy existuje jasná, o teoretická východiska opřená představa, ,jak věci fungují‘ a jaký je spouštěcí mechanismus klíčových jevů, (5) bere v úvahu kontext, ve kterém se změny odehrávají, (6) dokáže propojit rovinu individuálních zkušeností s rovinou společenskou, (7) dokáže propojit několik faktorů a trendů, často studovaných izolovaně. 
V prognostice existují v zásadě dva okruhy metod. První je založen na analýze dat z minulosti a jejich projekci či predikci do budoucna. Druhý je založen na formulaci žádoucích cílů, od kterých se dále postupuje „,dozadu“ a hledají se možné cesty k naplnění těchto cílů. V praxi je často potřeba tyto př́istupy zkombinovat.

I když jsou vznikající prognózy, vize a strategie, vázány na konkrétní společnost či stát, nelze je formulovat bez ohledu na kontext globalizujícího se světového společenství. V případě České republiky jsou to především vzájemně spjaté souvislosti a kontexty globalizace a evropské integrace. Novým, dosud ne zcela pochopeným fenoménem je globální krize, její př́íčiny a bezprostřední i dlouhodobé důsledky. Je nutno respektovat novou dynamiku evropské integrace, symbolizovanou přijetím Lisabonské smlouvy, která má posílit pozici Evropské unie v utvářejícím se multipolárním světě.

Témata souboru prognóz jsou tato: (1) Stárnutí populace ČR jako bezpečnostní hrozba. (2) Korupce, kriminalita a organizovaný zločin jako faktor nestability. (3) Od marginalizace AČR k evropskému řešení. (4) Hrozba kolapsu bezpečnostního systému ČR.

Témata souboru prognóz mají vnitřně logicky provázanou strukturu. Stárnutí populací je objektivním civilizačním procesem, který je charakteristický pro vyspělé země a vyžaduje z hlediska dalšího ekonomického rozvoje vyrovnávání populačního deficitu, což se při zvláště neřízeném procesu může stát a stává bezpečnostní hrozbou. Politickou nestabilitu vážně ohrožuje také korupce, kriminalita a organizovaný zločin jako důsledek nedostatečného způsobu vládnutí, slabosti demokracie a od sedmdesátých let minulého století prohlubující se sociální nerovnosti. To vyžaduje spolu s prohlubováním demokracie a zlepšováním sociální politiky mít v dobrém stavu systém bezpečnosti, zvláště jeho rozhodující složky jako je armáda a policie. V opačném případě hrozí kolaps tohoto systému, kterému je třeba především vládnutím s promyšlenými strategickými postupy předejít. Scénáře jsou zpracovány z pohledu roku 2020.

\section{Stárnutí populace ČR jako bezpečnostní hrozba}

Nebyli jsme v tom sami, nestárla jen naše česká populace, ale i evropská. Žili jsme stále déle. Nejlépe na tom byli na počátku druhé dekády 21. století občané Španělska, Francie, Itálie a na Kypru. Ženy se tu dožívaly 83 až 85 let, muži 78 až 79 let. Češi přibližně o tři až čtyři roky méně, tj. ženy 80 let a muži 75 let, ale u mužského pohlaví to bylo dva roky pod evropským průměrem. V Evropě žilo 718 milionů obyvatel, tj. žilo-li na planetě více než sedm miliard lidí, bylo to přes desetinu světové populace. Hustota zalidnění činila 72 obyvatel na km², nejvíce ze všech kontinentů. V zemích Evropské unie žilo 502 milionů obyvatel.

Demografická reprodukce ale vázla. Populační růst, zvláště v unijních zemích, zajišt'ovali hlavně přistěhovalci. Potvrdily to informace Evropského statistického úřadu o demografickém vývoji. Stabilizace počtu obyvatel vyžadovala, aby každá žena měla 2,1 dítěte, resp. rodina optimálně tři děti, protože část žen, resp. i mužů je neplodných. Taková situace byla jen v Irsku, kde se ženy měly v průměru 2,7 dítěte. Mírně spokojeni mohli být díky populační politice Francouzi, v zemi žily v rodinách průměrně dvě děti, výrazněji více dětí bylo v rodinách přistěhovalců. Nejhưřre se dařilo populační regeneraci Mad'arsku, Portugalsku a Německu. Obyvatel SRN ale po devíti letech opět přibylo. Koncem roku 2011 žilo v SRN 81,8 milionu lidí, 
o 92 tisíc více než rok předtím. Země tak po devíti letech poklesu opět zaznamenala přírůstek, oznámil Spolkový statistický úřad. Zvýšení není důsledkem vyšší porodnosti, ale toho, že v květnu 2011 skončilo sedmileté omezení pro občany z nových zemí EU pracovat v SRN.

Demografický vývoj byl nejvíce ohrožen v Rusku, ve kterém zvláště muži dosahovali ve srovnání s ostatní Evropou, zvláště západní, velmi nízkého věku 54 let, příčinou byl způsob života, zvláště alkoholismus. Navíc tu docházelo stejně jako na začátku devadesátých let minulého století ke generačním emigračním vlnám, které se opakovaly ke konci první dekády století a následně i na začátku dekády třetí.

Vlády evropských zemí si tento vážný i bezpečnostní handicap uvědomovaly. Populační politika přinesla určité úspěchy, za šest let se v Evropě zvedla porodnost z 1,47 dítěte na ženu na 1,6 dítěte. Podobný trend byl patrný do určité míry i v České republice. Porodnost po roce 1990 byla velmi nízká, pod 100 tisíc novorozenců. Vrcholu bylo dosaženo v roce 2009, kdy se narodilo téměř 120 tisíc dětí. Ale nikoli zvýšením přirozeného přírůstku, nýbrž jako důsledek většího absolutního počtu rodiček, narozených v 70. letech minulého století (v letech 1974 až 77 se každoročně narodilo 190 až 196 tisíc dětí). Situace se jako dozvuky ekonomické krize však začala zhoršovat, prvním signálem byl nebývalý jev, že některé rodiny ve špatné sociální situaci začaly odkládat své děti do sociálních zařízení v takovém rozsahu, že je vedení těchto zařízení musela odmítat. Vládní opatření tomu i rozšířenou pěstounskou péčí nedokázala čelit.

Od roku 2010 začala porodnost klesat a pokles stále trval a podle demografických prognóz tak mělo pokračovat dalších nejméně 50 let. Bylo tomu tak nejen u nás, ale i v řadě dalších evropských zemí. Nebýt přistěhovalců, počet obyvatel by kolem roku 2060 klesl na asi 7,5 milionu, v roce 2100 na 6 milionů, s přistěhovalci poté 8,8 milionu. Přirozený př́růstek se v roce 2010 pohyboval na hranici 1,4 . A poté bylo ještě hůř. Pro udržení počtu výchozích 10,5 milionu obyvatel jsme imigranty potřebovali. Evropa se proto musela sjednotit na přesně promyšlených pravidlech. V mnohém převzala dlouhodobě prověřenou imigrační politiku Spojených států.

Demografická struktura populace u nás stále výrazně ovlivňovala ekonomický růst a sociální rozvoj, a protože šlo o dvě provázané stránky jednoho procesu, stav ekonomiky zpětně působil na demografické chování populace, jehož důsledky se projevily na konci druhé dekády a pokračovaly i řadu dalších let. Migrace mohla tuto situaci řešit jen zčásti, navíc šlo o ambivalentní proces, který přinášel i mnoho problémů, zvláště v době finanční, ekonomické, sociální a společenské krize, kdy rostla nezaměstnanost, a proto docházelo k sociálním nepokojům. Místo legální práce i přes zvýšená represivní opatření byla tendence k práci nelegální. Spolu s tím rostla i kriminalita migrantů, protože krize vždy postihovaly především migranty.

V ČR v roce 2010 žilo 430 tisíc cizinců, nejvíc v hlavním městě, a to třetina. V Praze bylo z 1254317 občanů cca 150000 imigrantů, tj. 12\%. Nejvíce tu bylo Ukrajinců - 50 318, Slováků 17967 (více než dvacetinásobek Slováků, tj. $4 \%$ všech našich obyvatel ovšem mělo v ČR již české občanství), 17509 Rusů, 10699 Vietnamců, 3937 Č́ínanů, 3770 Američanů, 2633 Němců, 2061 Poláků, 1742 Bělorusů, 1285 Chorvatů, 1283 Italů, 851 Mongolů a 701 Moldavanů a dalších, tedy celkem 148123 cizinců, často se však uvádělo, že jich tu byl dvojnásobný počet. Jejich 
nárůst však nebyl již tak strmý (v roce 2008 jich přibylo 18 200, v roce 2009 jen 13 209, za devět měsíců roku 2010 pak 5291).

Cizinci měli vyšší kriminalitu - za deset měsíců roku 2010 spáchalo v Praze trestný čin 1615 cizinců, z toho pět vražd. V polovině listopadu 2011 se objevila informace, že v České republice bylo v říjnu zaměstnáno přes 107000 Slováků, což bylo nejvíce za posledních sedm let. Od roku 2004 jejich počet vzrostl o 47000 , tedy o $79 \%$. Vyplývalo to z údajů ministerstva práce a sociálních věcí.

Migrace a její důsledky se v souvislosti s pokračující finanční a ekonomickou krizí a událostmi v arabském světě se proto dostaly do popředí pozornost světového společenství i politických představitelů a občanské veřejnosti v České republice. Převažovalo přesvědčení, že migrace má nejen pozitivní účinky jako je vliv na ekonomický růst, ale je zároveň bezpečnostní hrozbou. Bylo to možné prokázat stovkami incidentů spojených i s násilím. Jejich společnou příčinou bylo nedostatečné řešení narůstajících problémů, což vedlo k růstu oboustranné xenofobie, extremismu a vytváření krajně pravicových politických seskupení. To postupně přispívalo k růstu politické nestability v Evropě i v jiných částech světa a k přijímání radikálních opatření při nezvládnutí situace demokratickými prostředky a výchovným úsilím. Týkalo se to především radikální části islámské populace.

Muslimů vyznávajících islámské náboženství, po křest’anství druhé nejrozšířenější náboženství v Evropě, žilo na počátku druhé dekády 21. století v Evropě 63 milionů, tj. téměř desetina obyvatelstva, v Evropské unii jich pak 16 milionů, nejvíce ve Francii - 6 milionů, z velkoměst nejvíce muslimů žilo v Moskvě, kolem jednoho milionu. Pokud jde o migrační politiku, zatímco Velká Británie preferovala integraci, Francie asimilaci. Odborníci na tuto problematiku byli přesvědčeni, že se proklamuje integrace, ale realizuje asimilační politika.

Pro muslimské rodiny byla charakteristická vysoká míra natality, což při nízké míře porodnosti ostatních, zvláště většinové populace místního obyvatelstva, vedlo ke zvyšování jejich podílu.

Diskuzní byla otázka, zda ze sociologického hlediska se u muslimů jedná o komunitu. Muslimští představitelé i muslimští věřící to odmítali a zdůvodňovali tvrzením, že mezi nimi je velmi slabá komunikace. České občany někteří muslimové obviňovali z islamofobie založené údajně na iracionálních emocích a na tabuizaci islámské problematiky bez věcné kritiky, kdy bylo vše o islámu a muslimech preventivně cenzurováno.

V Evropě byli muslimové v podstatě ve třech oblastech: historicky ve východní Evropě až po Polsko a na Balkáně, jako důsledek migrace byla třetí oblast v západní Evropě. Česká republika se ocitla v jakémsi jádru těchto tří enkláv, ale paradoxně bez výraznější muslimské přítomnosti.

Integrace muslimů jako podstatné migrační složky začala být hlavním politickým a společenským problémem západní Evropy od počátku 21. století, kdy tu počet muslimů neustále narůstal, takže se začalo mluvit o muslimské demografické revoluci. Jacques Rupnik uvedl, že zranitelnost našich společností souvisí s její otevřeností, a musíme proto znovu definovat poměr mezi svobodou a bezpečností. Dilema Západu bylo v tom, že byl nucen hájit svou svobodu na úkor jiných svobod.

Nové divoké „stěhování národů“ nastalo i jako důsledek dalších ekonomických, sociálních a ekologických krizí a katastrof doprovázených násilím zejména na jih 
od Evropy. Největší migrační vlny s převahou muslimů nastaly v polovině druhé dekády pro vyhrocení konfliktů mezi sunnity a šíity v iráckém prostoru a v jeho nejbližším okolí.

Politická korektnost dlouhého mlčení o integraci imigrantů a o problémech s menšinami byla prolomena vystoupeními Kevina Rudda, Davida Camerona, Angely Merkelové a Nicolase Sarkozyho, který dokonce pohrozil vystoupením ze schengenské dohody, pokud Evropa nezajistí své hranice před nelegální migrací. Smířlivý pokus Baracka Obamy změnit př́istup k muslimské civilizaci v jeho káhirském projevu se podařil jen zčásti.

Autoři mnoha scénářů varovali před tím, co se potvrzovalo v polovině první dekády 21. století, že narůstá propast mezi potřebami a aspiracemi veřejnosti a ekonomickou realitou, a že úsporné programy bez orientace na ekonomický a sociální rozvoj povedou $\mathrm{k}$ masivním veřejným protestům. A vyšší míra migrace tento rozpor ještě prohloubila.

Největší socioekonomické problémy s migrací narostly logicky a objektivně v oblastech, v nichž probíhaly společenské, politické, ekonomické a sociální konflikty, nemluvě o konfliktech vojenských. Přispěla k tomu i skutečnost, že se nepodařilo zastavit zvyšování vojenských rozpočtů v mimoevropském prostoru.

Jednou z cest řešení migračních problémů byla likvidace ohnisek napětí a prevence před vznikem dalších. Bylo zřejmé, že existuje jistá míra saturace, tj. schopnosti jednotlivých zemí a jejich obyvatelstva integrovat jiná etnika či skupiny do národního prostředí. Byla-li překročena, vznikly i uzavřené komunity a ghetta, jejichž existencí sílila i xenofobie přerůstající v rasismus, v určité míře i z pudu sebezáchovy. Rozhodovalo, jak byla konkrétní minorita schopná se integrovat, přizpůsobit se existujícím podmínkám, resp. jakou adekvátní reflexi byla majorita ochotna projevit a tyto minority asimilovat či integrovat.

Česká společnost si nebezpečí migrace a jejích následků uvědomovala a jednotlivé vlády k jejímu řešení přijímaly strategické a koncepční dokumenty. Složitější byla jejich realizace, kterou komplikovala častá výměna relevantních politických představitelů, nedostatek finančních prostředků a zčásti i nedostatek kvalifikovaných odborníků.

Na druhé straně bylo nutno přiznat, že migrační politika byla velmi složitá, vyžadovala nejen praktická opatření, ale i jasnou představu o modelu multikulturní společnosti, aby nevedla ke konfliktům a neoslabovala lidský a kvalifikační potenciál zemí, odkud migranti přicházeli, zvláště z rozvojových, což následně komplikovalo jejich ekonomický růst, zvláště když se migranti po získání zkušeností do svých zemí nevraceli.

Nemohlo proto být překvapením, když se v mnoha zemích včetně naší začínala vytvářet dvě politická uskupení: jedno se orientovalo na Evropskou unii a integraci, druhé se pod myšlenkou uchování státní suverenity formovalo nacionálně, v mnoha případech i národovecky, a proti oficiálně proklamovaným a zčásti realizovaným evropským integračním snahám.

V této souvislosti se nabízelo, zda naší skutečné suverenity v globálním světě nelze dosáhnout právě aktivní participací českého státu na evropských integračních snahách jako pravděpodobně jediné možnosti čelit ekonomické a politické konkurenci. Začalo se to prosazovat až po jistém vyřešení krize eurozóny a skončení finanční a ekonomické krize v bezpečnostní a vojenské oblasti. 
Pro naši republiku bylo přijetí schengenských dohod stále inspirativnější, zahrnovaly zkušenosti a opatření Evropské unie. Všeobecně se konstatovalo, že události v arabském světě prověřily smysluplnost těchto dohod. Migrace se musela stát stále více řízeným procesem, bylo nutno přijímat jen ty migranty, se kterými by nebyly v budoucnosti problémy. Zároveň Evropa stála před hledáním nového modelu uspořádání vlastní společnosti a úkolem modifikovat představu multikulturní společnosti.

Na konci druhé dekády století byla situace dost paradoxní. Zatímco v západní Evropě i přes dobré strategie v práci s menšinami, zvláště muslimskou, vznikaly problémy, výsledky v České republice charakteristické menší intenzitou integrace byly lepší. Bylo tomu tak mj. i proto, že se muslimští migranti naší zemi v podstatné míre vyhýbali.

S odstupem bylo nutné přiznat, že k tomu do jisté míry přispěla i určitá česká xenofobie, ateismus a obecně negativní vztah k církvím vyúst’ující až v antiklerikalismus. Xenofobie však byla do určité míry selektivní, neprojevovala se vưči sousedním národům, málo $\mathrm{k}$ Vietnamcům a Č́ńanům, ale silně proti muslimům, což bylo způsobeno především tím, že islám nepředstavoval jen náboženství, ale především styl života, který byl pro český národ nepřijatelný. Ale neopravňovalo to k tomu, aby Česká republika v populační politice polevovala.

\section{- Korupce, kriminalita a organizovaný zločin jako faktor politické a ekonomické nestability}

Náš půldruhabilionový státní dluh v roce 2012 byl z poloviny způsoben důsledky privatizace a z ní vyplývající nutnosti sanovat banky, a z druhé poloviny daňovou soustavou, která nekryla státní výdaje. Sociální systém k tomu přispěl jen zneužíváním dávek části jejich uživatelů. Zbavit se v budoucnosti dluhů a mít přebytkový státní rozpočet bylo možné jen za předpokladu, kdyby vlády boj proti korupci myslely vážně, protože podle odhadů jsme tím přicházeli ročně o sto miliard korun, a šedá ekonomika způsobila škody přinejmenším dvojnásobné. Podle Transparency International jsme v roce 2011 ve vnímání korupce klesli z 53. místa na 57., byli jsme na samém konci evropských zemí a mezi zkorumpovanými zeměmi africkými, asijskými a latinskoamerickými.

Mezi občany naší země převládlo přesvědčení, že korupce je nejnebezpečnější deviací, která ohrožuje sociální soudržnost a demokratický charakter občanské společnosti. Boj proti korupci se však stal na začátku druhé dekády 21. století spíše bojem mocenským než věcným, a to se všemi negativními důsledky včetně posílení tendencí k návratu k autoritativnějšímu a autokratičtějšímu politickému systému. Hlavním problémem se nestala individuální korupce, ale systémová, jak k tomu dospěla i pracovní skupina Národní ekonomické rady vlády pro boj proti korupci. Někteří kritici dospěli k závěru, že korupce naši demokracii změnila v oligarchii mocenských elit, čímž se boj proti ní stal současně bojem za záchranu demokracie. Základem úspěchu byla reforma financování politických stran daňovými asignacemi, kterou se ale nepodařilo dostatečně pro samotný odpor politických stran vyřešit. Svědčily o tom např́klad okolnosti s odškodněním církve, kde se jeho 
výše radikálně snížila, tzn., že odškodnění bylo spojeno s politickými zájmy. Podobně tomu bylo i s gigantickou ekologickou zakázkou, která na konec musela být pod tlakem médií a veřejnosti zrušena.

Analýzy veřejného mínění varovaly, že proti korupci by individuálně bylo ochotno zasáhnout jen $6 \%$ obyvatelstva. Naopak polovina, tj. $48 \%$ paradoxně uznávala funkčnost korupce ve státní správě, bez níž by údajně ani nefungovala. Většina $59 \%$ obyvatel považovala úplatky za normální součást společenské praxe. A $69 \%$ se otevřeně hlásilo ke klientelismu, tj. souhlasilo s názorem, že nejlepší životní strategií je mít dobrého přítele na správném místě. Bylo dalším paradoxem, že lidé i protikorupční občanské iniciativy chtěli, aby proti korupci bojovaly především státní orgány, které považovali za nejviditelněji zkorumpované.

Vláda prezentovala boj proti korupci jako úspěšný. Přitom byla situace zpočátku zcela opačná. Vláda a její orgány nebyly iniciátory odhalování korupce, jen o ní většina politiků mluvila, odhalování korupčních kauz bylo většinou dílem několika odvážných a úspěšných investigativních novinářo deníků a časopisů. A také anonymů. Politická scéna byla spíš úspěšná v tom, jak výsledky policie, státních zastupitelství a soudů i prostřednictvím ovlivnitelných pracovníků těchto orgánů mařit. Pražské zastupitelství bylo smutným př́kladem. Politici z ministerských postů odcházeli až poté, když se jejich postavení stalo neudržitelné, jako tomu bylo v prrípadě ministra životního prostředí, dopravy, kultury a průmyslu a obchodu. Následně se však přece jen některé kauzy dostaly před soud.

V konfrontaci s tím byly sice problémy s tzv. nepřizpůsobivými svízelné a daly se řešit v některých př́ípadech až v řádu generací, ale rozhodně nezpůsobovaly republice takové finanční škody jako korupce, která navíc lámala charaktery, prohlubovala nedůvěru $\mathrm{k}$ politikům i $\mathrm{k}$ demokratickému politickému systému a stala se faktorem politické a ekonomické nestability, tj. neustále hrozily demonstrace a násilnosti.

Stálým problémem České republiky byl stav kriminality, která ve srovnání s minulým režimem zvýšila trojnásobně. Navíc po čtyřech letech poklesu v roce 2011 znovu vzrostl počet zjištěných trestných činů o 1,2\%, celkem bylo v Česku spácháno 317177 trestných činů. Na tomto počtu evidovaných porušení zákona se více než $60 \%$ podílela majetková trestná činnost, především krádeže. Těch bylo v ČR zaznamenáno 203 675, přičemž převládaly krádeže kapesní, krádeže osobních automobilů nebo věcí z nich (téměř 60 tisíc případů) a krádeže vloupáním do domů, bytů a chat (14 414 případů). To s velkou mírou pravděpodobnosti svědčilo o vlivu finanční a ekonomické krize, při níž se pod hranici chudoby dostávalo stále více lidí.

Násilných trestných činů v roce 2011 policie vyšetřovala 19 409, což představovalo ve srovnání s rokem předchozím více než $7 \%$ nárůst. Vražd se stalo stejně jako v roce 2010, tedy 173 . U loupeží policie zaznamenala pokles o 2,9\%, spácháno jich bylo 3761. Výrazný nárůst kriminality policie zaznamenala u výroby a držení dětské pornografie, kriminalisté odhalili 193 případy, což bylo o $48 \%$ více než v roce předchozím. O $15 \%$ se výšil také počet znásilnění, kterých policie vyšetřovala 675 . Největší nárůst trestné činnosti policie evidovala v Moravskoslezském kraji (6,9\%) a v Olomouckém kraji (4,6 \%). Nejvyšší registrovaná kriminalita byla v Praze (74 122 skutků), v Ostravě (18 624), Brně-městě (16 069) a v Karviné (9798). 
Program prevence kriminality se proto soustředil na snižování míry a závažnosti trestné činnosti a zvyšování pocitu bezpečí občanů, na snížení výskytu delikventní činnosti u cílových skupin definovaných ve strategii prevence kriminality, nebo jejich ochrana, na efektivní a koordinovaný systém prevence kriminality a na komplexní přístup v komunitách postavený na spolupráci obce, Policie ČR a dalších subjektů. Stav kriminality se však po celou dekádu podstatněji nezměnil.

Jednu z klíčových bezpečnostních hrozeb představoval organizovaný zločin, který byl nebezpečným jevem v každé době, ale v době globalizace představoval pro civilizaci jednu z nejzávažnějších bezpečnostních hrozeb. K jeho posílení došlo po rozpadu bipolárního světa a autoritativně řízené socialistické soustavy, především v Sovětském svazu a v Jugoslávii. V tu dobu se rozpadl represivní aparát a byly otevřeny dosud přísně střežené státní hranice. To umožnilo globální působení organizovaného zločinu, jehož uskupení se v těchto zemích vytvořila, a v převratovém chaosu došlo k jejich posílení. Přispěla k tomu také bezpečnostní nestabilita v podstatě ve všech světadílech jako důsledek lokálních ozbrojených konfliktů, které vedly dokonce i ke vzniku tzv. zhroucených států, které se staly ideálními základnami organizovaného zločinu. Příkladem za všechny může být Somálsko ohrožující svobodnou plavbu po oceánech a mořích ozbrojeným pirátstvím, proti čemuž se spojenecké země musely společně postavit.

Finanční a ekonomická krize organizovaný zločin posílila včetně jeho vzájemných vazeb a vytváření účinných vlivových sítí. Bylo tomu tak i v celé druhé dekádě 21. století, kdy organizovaný zločin používal stále sofistikovanější postupy a vzhledem k úsporným opatřením v bezpečnostním systému dokázal být vždy lépe vybaven moderními technickými prostředky než policie. Nezákonné aktivity organizovaného zločinu byly spojeny s ilegální migrací, pašováním lidí, zboží a zbraní, prostitucí, výrobou a distribucí drog, praním špinavých peněz a mnoha dalšími nezákonnými jevy, což vedlo ke stomiliardovým škodám. Podílelo se na tom podle odhadů jen v Evropě kolem čtyř tisíc uskupení. Některé skupiny byly zapojeny i do tzv. kyberválky.

Nejvážnější škody organizovaný zločin zpo̊sobil ve spojení s politickými elitami, jak k tomu došlo i v ČR, a i v oblasti privatizace bezpečnosti rozšířením působnosti soukromých bezpečnostních služeb.

Podle ministerstva vnitra organizovaný zločin představoval pro českou společnost nejzávažnější nevojenskou hrozbu. Zločinecké skupiny podrývaly společenské uspořádání, narušovaly stabilitu ekonomiky, podkopávaly demokratické struktury a ohrozily existenci právního státu.

Problém byl v tom, že téměř veškerá závažná trestná činnost, páchaná v ČR, nesla prvky organizovanosti. Pachatelé častěji operovali ve skupinách, jejichž vnitřní organizace a postupy byly čím dál sofistikovanější. Mezi hlavní trendy organizovaného zločinu patřily diverzifikace a rozšiřování nelegálních aktivit k méně násilné a méně rizikové, o to více výdělečné trestné činnosti.

Nejefektivnější zbraní organizovaného zločinu byla přizpo̊sobivost, rychlejší, levnější a kvalitnější komunikační technologie a transport a prostupnost státních hranic v EU. Zločinecké skupiny byly podle rezortu vnitra tvořeny převážně na základě národnostní příslušnosti a uchovávaly si úzké vztahy s domovským prostředím a s diasporami v sousedních zemích. U nás to kromě českých skupin 
byly nejaktivnější skupiny vietnamské, albánské (především z Kosova a Makedonie), ukrajinské, ruské, gruzínské, arménské, nigerijské, bulharské, rumunské a arabské.

Mezi nejvýnosnější aktivity patřila hospodářská kriminalita, nelegální migrace a obchod s lidmi, výroba a distribuce omamných a psychotropních látek a krádeže aut. Škody každoročně činily několik miliard korun. A ani v této oblasti nedošlo během desetiletí k podstatným změnám.

ČR se nemohla vymanit z ekonomických problémů, což podvázalo i výdaje na bezpečnostní systém. Nebyla ani vůle podstatněji změnit transparentnost financování politických stran. Proto i na konci druhé dekády byla korupce, kriminalita a organizovaný zločin faktory politické a ekonomické nestability.

\section{Od marginalizace AČR k evropskému řešení}

S odstupem více než dvou desítek let bylo už možné obecně konstatovat, že formování československé a následně zejména české armády nebylo ani tak výsledkem subjektivního cílevědomě řízeného strategického procesu, ale spíše jen důsledkem objektivního světového a evropského vývoje, zčásti i vývoje vnitropolitického. A to přesto, že bezprostředně po listopadových událostech se projevovala jistá tendence řídit společenské procesy v souladu s určitou dlouhodobější vizí a směřováním k cílovému stavu ve formě modelové představy alespoň způsobu řízení a organizačních struktur schopných produkovat bezpečnostní politiku, včetně obranné, odpovídající moderním vývojovým trendům.

Výsledkem takto spíše spontánně vytvořeného přístupu byla transformace československé armády útočného typu jako součásti Varšavské smlouvy v armádu expediční v rámci Severoatlantické aliance, v níž byly např. speciální síly podřízeny zpravodajským službám. Cílevědomě o přetvoření armády v expediční sbor usilovala pouze ODS v době, kdy byl stínovým ministrem obrany Petr Nečas. Úvahy o naší armádě jako ozbrojené síle sloužící obraně země se ve srovnání s faktickou situací v našem geopolitickém prostoru ukázaly sice zdánlivě vlastenecké, ale ve skutečnosti neodpovídající možnostem a realitě.

Počty vojáků československé armády se od druhé světové války pohybovaly v rozmezí od 150000 do téměř 300000 osob. Z toho přibližně čtvrtinu tvořili vojáci z povolání. V rezortu obrany bylo na přelomu roku 1989-1990 cca 210 tisíc vojáků a 50 tisíc občanských pracovníků, na počet obyvatelstva po Izraeli a Severní Koreji nejvíce. Po podpisu smlouvy o konvenčních ozbrojených silách v Evropě na pařǐžském summitu Konference pro bezpečnost a spolupráci v Evropě 19. 11. 1990 a její ratifikaci 19. 7. 1991 předložila ČSFR počty hlavních druhů výzbroje a vojenské techniky: 3315 bojových tanků, 4593 bojových obrněných vozidel, 3485 dělostřeleckých systémů, 446 bojových letounů a 56 bojových vrtulníků. Podle smlouvy byly pro ČSFR stanoveny následující maximální počty hlavních druhů výzbroje a techniky: 1435 bojových tanků, 2050 bojových obrněných vozidel, 1150 dělostřeleckých systémů, 345 bojových letounů a 75 úderných vrtulníků. Nadpočetná technika byla k 1. lednu 1992 soustředěna na shromažd'ovacích místech k plánované likvidaci. Jednalo se o 1880 tanků, 2453 bojových obrněných vozidel, 2335 dělostřeleckých systémů ráže 100 mm 
a výše a 101 bojových letounů. Zmíněný dokument stanovil limit pro početní stav armády na 140000 osob.

Od vstupu smlouvy v platnost zničila česká armáda do 16. listopadu 1995 celkem 4207 kusů smlouvou omezované techniky, z toho 1179 bojových tanků, 1470 bojových obrněných vozidel, 1498 dělostřeleckých systémů a 64 bojových letounů. Náklady spojené s touto likvidací přesáhly 105 milionů Kč. Zbývající technika se sice dala využít, ale pro armádu posléze byla spíše zátěží. Podle statistiky měly ozbrojené síly České republiky k 1. lednu 2011 v majetku 166 bojových tanků, 494 bojových obrněných vozidel, 244 dělostřeleckých systémů, 38 bojových letounů a 25 bojových vrtulníků.

Pokud jde o počty a personální strukturu, nepodařilo se udržet plánovaný početní stav AČR v souladu se záměrem dokumentu Transformace rezortu Ministerstva obrany ČR z roku 2001 ve výši 26200 vojáků. Skutečný počet k 1. lednu 2012 ve výši 21751 vojáků a 8241 občanských zaměstnanců se měl po snížení rozpočtu snížit v roce 2014 na 16000 a 6000 občanských zaměstnanců, což se nemohlo nepromítnout do další redukce schopností armády.

Tato situace ovlivňovala také strategické myšlení důstojníků a generálů. Zatímco dřive většinou absolvovali stupně velení družstvo - četa - rota - prapor - pluk brigáda x divize - sbor - armáda - okruh - generální štáb - ministerstvo obrany, po transformaci a profesionalizaci armády obvykle odcházeli na strategický stupeň řízení a velení přímo z taktického stupně, tj. velení praporu, většinou bez zkušenostní na operačním stupni (brigáda).

Tento fakt mohl být a nejspíš byl handicapem, a to bez ohledu na skutečnost, že se v expediční armádě vojáci připravovali na asymetrickou válku, kde do jisté míry hraje úlohu tzv. swarming, který Sean Edwards definuje ,jako doktrinální přístup proponující primárně taktický organizační princip, který favorizuje bojovou činnost vedenou prostřednictvím decentralizovaného kolektivu autonomních nebo semiautonomních vysoce mobilních entit, které operují v různých vektorech (majoritně se jedná o diferenci v topologické orientaci a intenzitě úderu) a konstantně se přeskupují do optimální bojové konfigurace - zde je pak znovu dominantně aplikováno již zmíněné pulzní paradigma“.

Proti tvrzení, že se armáda proměnila v expediční sbor, se logicky a zákonitě objevily námitky. A sice že armáda jen nabyla schopnost vytvářet úkolová uskupení, která jako moduly vstupují do společných spojeneckých operací nejrůznějšího typu. Od mírotvorných až po bojové. Ani v nejmenším nerezignovala na obranu vlastního státního území a byla připravena k naplnění článku 3 Washingtonské smlouvy v celé své schopnosti. Tato schopnost byla dána závaznou ambicí postavit pro všechny případy jako významný operační modul jedno brigádní uskupení na bázi střední brigády se všemi potřebnými podporami. Takové také bylo strategické a operační plánování NATO pro všechny předpokládané situace včetně situací, v nichž by byl aktivován článek 5 Washingtonské smlouvy.

Bezpečnostní politika včetně obranné se postupně dostala do situace, která byla anticipována již na začátku devadesátých let v Institutu pro strategická studia, a sice že ekonomická hrozba se může stát vážnější hrozbou než vojenská. To se stalo na začátku druhé dekády století faktem i u nás, bylo ale otázkou, jak dalece budeme schopni se s tím vypořádat, bude-li vůbec v naší moci, aby špatnou bezpečnostní 
politikou se postupně v našem geopolitickém prostoru nevytvořila situace, kdy potenciálním vojenským hrozbám už nebudeme schopni čelit.

Nebyli jsme v situaci atypické. I bezpečnostní a obranná politika členských zemí NATO a EU byla se všemi důsledky zásadně ovlivňována ekonomickou a finanční krizí EU a Spojených států. Evropští členové NATO sice měli stále vydávat $2 \%$ HDP na obranu, tento závazek však pro finanční a ekonomickou krizi s výjimkou Velké Británie, Francie, Itálie, Řecka a Turecka ve většině zemí dodržován nebyl, obranné výdaje se snižovaly a v jejich snižování se pokračovalo. SRN plánovala snížit vojenský rozpočet do r. 2014 o 27 \%, Velká Británie o 7 \% do roku 2015, Francie o 3,6\% do roku 2014, což bylo i realizováno a ve snižování obranných výdajů se pokračovalo. Nebylo přitom možné přehlížet, jak se s těmito prostředky ve většině zemí neefektivně hospodařilo, a to nejen pokud jde o korupci, ale důsledky špatných rozhodnutí, např. o pořízení zbraňových systémů pro současný způsob boje nevhodných. Př́́kladem za všechny byla výroba a nákup letadel L-159.

Jen tak mohlo dojít k tomu, že se začala prohlubovat malá schopnost bojového nasazení vojenských sil a prostředků evropských členů NATO. Z celkového početního stavu 1,5 milionu vojáků bylo schopno nasazení v zahraničních misích jen pouhých cca 3-5\% vojáků a úbytkem misijního nasazení schopnost dále klesala, což vedlo ke zcela logickému tlaku početní armádní stavy a jejich výzbroj a výstroj snižovat. Terčem kritiky se stala i bojová uskupení EU (EU battlegroups), a to pro nedostatečné vybavení pro vedení vojenských operací. Podobně se začal kriticky posuzovat fakt, že evropští členové NATO, resp. EU, neměli k dispozici dostatek klíčových komponent pro vedení bojových operací, zejména zařízení pro sledování vzdušného prostoru, resp. bojiště, velká vojenská transportní letadla, munici atd.

Evropská obranyschopnost se začala snižovat také jako důsledek toho, že Spojené státy americké postupně v souladu se svou novou vojenskou doktrínou z roku 2011 přesunuly priority bezpečnostní a obranné politiky do východní a jihovýchodní Asie, což se ukázalo jako strategické rozhodnutí stejně chybné jako rozhodnutí o Afghánistánu a Iráku, protože to vedlo k eskalaci napětí a zvyšování zbrojní výdajů jak Číny, tak proti původním záměrům i Spojených států, mohly si to ale dovolit jen proto, že v polovině druhé dekády století skončila ekonomická recese a nastalo období růstu.

Přesunem těžiště do prostoru Asie si Spojené státy moc nepomohly, protože expanze Číny byla a dále pokračovala především jako ekonomická a demografická. Číñané nepotřebovali konflikt s Ruskem kvůli Sibiři, postupně se jí zmocňovali migrací, objektivně determinovanou i důsledky čínské populační politiky, která vedla k převaze mužů nad ženami v poměru 100:113, tj. k přebytku desítek milionů mužů.

Nová vojenská strategie USA podstatně překonala Národní bezpečnostní strategii USA ze září 2002. Ta měla preventivní charakter takzvaného preemptivního typu. Což znamenalo, že Američané mohli preventivně vyvolat vojenský konflikt, jak se skutečně stalo v Afghánistánu a v Iráku, v prvém případě se souhlasem OSN, v druhém ne. Vést dva ozbrojené konflikty umožňovala strategie vojenská. Zásadní změny vojenské strategie USA připravoval již bývalý ministr obrany Robert Gates, jediný republikán v Obamově demokratické vládě. Ministr obrany Leon Panetta, bývalý ředitel zpravodajské služby CIA, spolu se šéfem amerického sboru náčelníků štábů Martinem Dempseyem ji poté vyhlásili. Podle Obamova zadání měla 
snížit finanční náročnost, ale zároveň zajistit obranu a vojenskou převahu. Mnohá opatření se dala očekávat.

Pentagon musel respektovat, že Spojené státy měly dluh ve výši 15 bilionů dolarů. Armáda měla proto za př́íších deset až dvanáct let ušetřit 450 miliard, na konec však kvůli finančním dluhům musela ušetřit téměř bilion USD, což se jí podařilo jen proto, že nejen ukončila bojové akce, ale do konce druhé dekády let se do žádných nových nezapojila. Rozpočet amerického ministerstva obrany na rok 2012 byl proto jen 662 miliard dolarů (13,4 bilionu korun), tzn. ve srovnání s minulým rokem o 43 miliard nižší. Tedy cca o patnáctinu, což sice nebylo mnoho, ale pro americkou armádu znamená snížit počty o $12 \%$. Jak se dalo také čekat především v Evropě, Američané tu už málem sedm desetiletí od druhé světové války nehodlali držet své vojáky v takovém počtu. Z evropského kontinentu odešla jedna americká brigáda o počtu 7000 vojáků, zůstaly zde jen dvě, z nichž v polovině druhé dekády jedna byla také přemístěna do prostoru jihovýchodní Asie. Posléze začala oslabovat svou vojenskou sílu i v tomto prostoru.

Američané odstoupili od záměru mít tak silnou armádu, aby byla schopna vést dvě vítězné války najednou. Zkušenost s paralelním vedením války v Afghánistánu a v Iráku byla pro ně dostatečně varovnou. Zvláště poté, kdy se přes odpor nevyhnuli ani podpoře povstalců v Libyi, která byla iniciativou francouzského prezidenta Nicolase Sarkozyho a britského premiéra Davida Camerona. Nakonec podpora vzpour tzv. arabského jara vedla v mnoha arabských zemích k nastolení islámské moci. Pro Američany nikdy nebyl problém svou vojenskou mocí vést vítěznou válku, ale zvládnout poválečné mírové uspořádání se jim v podstatě podařilo jen v Evropě po dvou světových válkách a v Japonsku po druhé světové válce.

Překonaná ekonomická krize a odchod spojeneckých vojsk z Iráku a v Afghánistánu se v polovině druhé dekády staly přelomem a inspiračním impulzem pro směřování $\mathrm{k}$ hlubší evropské integraci a v bezpečnostní oblasti k efektivnějšímu prohloubení a rozšíření vojenské spolupráce členských států NATO a EU. Nebylo by to bývalo možné, kdyby nebyly překonány tendence určitých politických sil k posilování nacionalismu.

Integrační tendence se zprvu úspěšně projevily v rozvoji konceptu ,pooling and sharing“, tj. posilování vojenské spolupráce mezi členskými státy EU (společný výcvik, společná vojenská cvičení, sdílení vojenských kapacit a logistiky). Podobný koncept vznikl v rámci NATO, jednalo se o tzv. ,,smart defence“, rozvoj tzv. „ostrovů vojenské spolupráce“ vedoucích k prohlubování regionální vojenské kooperace. Nejvýrazněji to bylo patrné např. ve francouzsko-britské vojenské spolupráci a ve vojenské spolupráci severských zemí - Dánska, Finska, Islandu, Norska, Švédska. Poté následovala také spolupráce zemí V4, tj. České republiky, Polska, Slovenska a později i Mad’arska, kde překonání nacionálních tendencí trvalo delší dobu. Podstatně se zvýšila také role Evropské obranné agentury (EDA) při prohlubování vzájemné spolupráce ve vývoji a nákupu vojenské techniky v EU, např. se podařilo překonat neefektivní model nákupu vojenské techniky, kdy v $75 \%$ prrípadů nakupovaly členské země vojenskou techniku samostatně. Prohloubila se spolupráce i při ochraně vzdušného prostoru.

Rozhodujícím momentem byl vznik operačního velitelství EU jako nástroje k rychlému rozmist’ování vojenských sil a prostředků armád členských států EU. 
Původně polskou myšlenku se podařilo realizovat s podporou Francie, Německa, Itálie a Španělska v roce 2019, shodou okolností k 70. výročí Severoatlantické aliance. Náplní činnosti velitelství bylo koordinovat aktivity ozbrojených sil členských zemí. Ta se při zachování jistých kapacit pro eventuální mezinárodní mise především věnovala obraně a ochraně hranic evropských zemí, zvláště členů EU a Aliance, eminentně prostoru schengenských dohod. Do konce druhé dekády se nikdo neodvážil i př̀i vytvoření složité situace v některých oblastech a zemích řešit je vojenskou silou. Ozbrojené síly se proto věnovaly preventivním aktivitám proti nežádoucím migračním vlnám i asistenci při řešení vnitřních nepokojů. Když se na začátku druhé dekády století objevovaly podobné scénáře, navrhovali někteří skeptičtí kritici dát jim nějaký pohádkový titul, cosi à la Jak dědeček měnil, až vyměnil, Chytrá horákyně nebo Brémští muzikanti.

Česká republika měla sice na začátku druhé dekády novou Bezpečnostní strategii ČR 2011 a Bílou knihu o obraně ČR, ale jejich reformní a rozvojové záměry spolu s cílem předejít rozpočtovému a personálnímu kolapsu armády i dalších bezpečnostních složek pro rozsáhlé rozpočtové škrty a dlouhodobé neefektivní vydávání prostředků na obranu (od listopadu 1989 dosáhly obranné výdaje celkem cca 1,3 bilionu korun) ztroskotaly. Záměr se nezdařil podle názoru některých bezpečnostních a vojenských odborníků mj. i proto, že nebylo jasné, co vlastně bezpečnostní strategie a Bílá kniha o obraně představují: nebyly podkladem pro novou bezpečnostní a obrannou strategii, jak bylo deklarováno, staly se spíše pokusem o koncepci výstavby ozbrojených sil. Záměry definované v Bílé knize o obraně byly konfrontovány s tvrdou realitou dalšího omezování vojenského rozpočtu, což nutně muselo tyto ambice zásadně korigovat. I přes úsilí rezortu obrany se nepodařilo, aby se Bílá kniha o obraně opět stala jedním z mnoha stěží realizovatelných reformních dokumentů, jichž byla od počátku existence AČR vypracována řada.

Armáda nebyla schopna doplňovat kontinuálně, tj. plynule po jednotlivých ročnících nebo alespoň věkových kohortách své stavy, a proto logicky stárla a blížila se neúnosné hranici průměrného věku blízkému čtyřiceti létům. Po ukončení zahraničních misí ztratila armáda další faktor své přitažlivost a vzhledem k nízkému sociálnímu zabezpečení ztratila vážnější místo na trhu práce. I přes nízké finanční a materiální zabezpečení vojáků, mandatorní výdaje začaly z 50 \% vojenského rozpočtu postupně stoupat až k $75 \%$. Navzdory finanční situaci nebyl rezort schopen podstatně optimalizovat počty ve vrcholových řídících a velitelských strukturách. Pro nedodržování závazků a slibů ztrácelo vedení rezortu v očích vojáků kredit. Vnitřní dluh armády překročil hranici sto miliard korun. Nebyla proto ani schopna zachovat deklarovanou úroveň vojensko-politických ambicí ČR a hrozilo nedodržení spojeneckých závazků vůči NATO a EU. Podstatně se nezlepšila úroveň a kompetentnost civilního řízení a kontroly armády. Za této situace i přes jistý odpor nacionálně orientovaných politiků a politických uskupení nezbylo než se připojit k evropskému integračnímu úsilí i v oblasti bezpečnosti a obrany.

Za této situace bylo srozumitelné, když vedení ministerstva obrany bojovalo za zvýšení rozpočtu rezortu. I když to bylo především věcí vlády, zároveň bylo nutno získat podporu veřejnosti. Ta byla jistě možná, ale jen za určitých předpokladů, tj. po předložení analýzy, jak se v rezortu se svěřenými prostředky hospodařilo, jakou hodnotu ze stomiliardových rozpočtů armáda má. To se nikdy nestalo. 


\section{- Hrozba kolapsu bezpečnostního systému ČR}

K zajištění svých bezpečnostních zájmů Česká republika vytvářela a rozvíjela komplexní hierarchicky uspořádaný bezpečnostní systém, který integroval subsystémy vnitropolitické, zahraničněpolitické, vojenské, vnitřně-bezpečnostní, hospodářské, finanční, legislativní, právní, sociální a ochranu obyvatel. Systém byl zajištěn legislativou, která stanovovala působnost a vzájemné vazby jeho jednotlivých složek (moci zákonodárné, výkonné, soudní, územní samosprávy a právnických a fyzických osob). Bezpečnostní systém ČR měl plnit funkci institucionálního rámce a nástroje při tvorbě a realizaci bezpečnostní politiky.

Základní funkcí bezpečnostního systému ČR bylo podle Bezpečnostní strategie České republiky 2012 řízení a koordinace činnosti jednotlivých složek odpovědných za zajišstování bezpečnostních zájmů ČR. Zajištování bezpečnosti ČR nemohlo být podle tohoto dokumentu pouze záležitostí složek, které jsou k tomu výslovně určeny, ale svým právně stanoveným podílem k němu přispívaly jak státní orgány a orgány územní samosprávy, tak i právnické a fyzické osoby.

Struktura bezpečnostního systému zahrnovala zejména prezidenta republiky, Parlament ČR, vládu, Bezpečnostní radu státu a její pracovní orgány, ústřední správní úrady, krajské a obecní úřady, ozbrojené síly, ozbrojené bezpečnostní sbory, zpravodajské služby, záchranné sbory, záchranné služby a havarijní služby.

Za zajištování bezpečnosti státu a za řízení a funkčnost celého bezpečnostního systému ČR byla odpovědná vláda jako vrcholný orgán výkonné moci. Funkční bezpečnostní systém představoval nejen nástroj pro účinné zvládání krizových situací vojenského i nevojenského charakteru, ale zajištoval i prevenci a př́ípravu na možné krizové situace a jejich včasnou identifikaci a varování.

Fungování bezpečnostního systému, výstavba a rozvoj schopností jeho jednotlivých složek, hospodářské a finanční zabezpečení představoval dlouhodobý a náročný proces využívající praktických zkušeností jednak z řešení různých krizových situací, jednak ze systematické přípravy a preventivního působení jednotlivých složek. Bezpečnostní systém musel neustále reagovat na měnící se podmínky a změny $\mathrm{v}$ bezpečnostním prostředí a vznikající nové hrozby. $\mathrm{Z}$ tohoto důvodu bylo potřeba bezpečnostní systém ČR potřeba vnímat jako otevřený a dynamicky se vyvíjející systém. Tolik k povinnostem bezpečnostního systému naší země, jak je vymezila Bezpečnostní strategie České republiky 2012.

Tento systém se postupně od počátku druhé dekády století dostával na práh kolapsu jako důsledek negativního synergického efektu vážných problémů v jeho klíčových složkách, tj. v armádě, policii, hasičském záchranném sboru a zčásti i zpravodajských službách.

Základní př́̌činou byl nedostatek finanční prostředků na udržování těchto klíčových složek bezpečnostního systému. Bylo tomu tak kromě subjektivních příčin proto, že vláda nedokázala výrazněji zastavit korupci, která podle Transparency International odčerpávala každoročně až sto miliard korun. Daleko vážnějšś škody, i když to nebylo v takovém popředí pozornosti, způsobovala černá ekonomika, nelegální zaměstnávaní (zvláště cizinců), tzv. švarcsystém, benevolentní daňové paušály pro živnostníky a svobodná povolání, nedostatečná schopnost vybírat daně, podvody s DPH ad., což se dařilo řešit opožděně a ne zcela důsledně. 
Jistou možností jak zvýšit státní př́ijmy bylo přijetí progresivní daně pro fyzické osoby, zvýšení daně velkým korporacím a zavedení daně z majetku, ale to bylo proti obsahu programu koaliční vlády. Neodhodlala se ani vrátit k daňovému systému, který existoval do roku 2006. Vláda volila zvyšování DPH, což vedlo ke snižování spotřeby a menšímu výběru právě DPH. Poškodilo to zejména nejchudší vrstvy, ale výrazně i střední třídu. Kdyby byly progresivně zdaněny nejlépe situované vrstvy, zachovaly by si svou úroveň spotřeby a na výběru DPH by se to v podstatě neprojevilo.

Rozpočtové úspory se velmi dotkly Armády České republiky. Kvůli nim nemohly být realizovány cíle Bílé knihy o obraně České republiky. Stále větší část rozpočtu rezortu obrany musela být vynakládána na mandatorní výdaje. Ačkoli výdaje vojenského rozpočtu brzy dosáhly výše 1,5 bilionu korun, a to nominálně, ne s připočtením inflace, přesto finanční hodnota armády byla velmi nízká a dále nízkými výdaji na investice a stárnutím zbraňových systémů a zařízení klesala. Už tím se armáda marginalizovala.

Z první dekády 21. století byla armáda zatížena deficitem financování ve výši přes 90 miliard Kč, který rychle přerostl přes 100 miliard Kč a stoupal dál, což se promítlo do schopnosti zachovávat deklarovanou úroveň vojensko-politických ambicí ČR a dodržení spojeneckých závazků vůči NATO a EU. Přitom se snížily platy vojáků, byly zdaněny př́íspěvky na bydlení i výsluhové důchody. To vedlo k prohloubení nedůvěry vojáků z povolání ve vedení rezortu a zčásti i velení armády a k oslabení zájmu o službu v profesionální armádě na trhu práce. Atraktivnost vojenského povolání dále redukovalo skončení zahraničních misí.

Podobná situace byla i v Policii České republiky. Nejvíce se jí na začátku druhé dekády 21. století dotklo neuvážené krácení provozních výdajů, takže se situace stala kritickou. Na obvodních odděleních musel být zrušen směnný režim služby, což vedlo k tomu, že policistům byl odebrán zvýšený základní tarif, tj. 10\% základního tarifu. Některým policistům se snížil plat až o pětinu. Větším problémem se stal fakt, že nebylo možné jako dosud zabezpečit nepřetržitý chod oddělení včetně povinné existence stálé služby podle interních předpisů. Snížení výdajů na pohonné hmoty vedlo k prodlužení doby dojezdu k trestným činům. Policisté přestali mít dostatek prostředků na zařízení na testy alkoholu. Došlo i k nebývalým opatřením, např. přísnému zákazu informovat o stavu v policii nejen občany, ale i představitele státní správy a samosprávy. Přri případné návštěvě ministra vnitra se mělo tvrdit, že je vše v pořádku, že nemají s úsporami nejmenší problémy. Byl stanoven strop počtu policistů na 40000 služebních míst, tj. jeden policista na cca 260 občanů. Soukromé bezpečnostní služby měly ve srovnání s policií výrazně vyšší počty, což mohlo být ve specifických situacích i bezpečnostní hrozbou.

Z uvedených a dalších důvodů došlo k dočasnému snížení objasněnosti trestné a jiné protiprávní činnosti. Vytvořila se nepřehledná situace v přiznávání osobních příplatků a odměn, což se prostřednictvím médií dostalo k občanům a vyvolalo nepř́ijemnou odezvu. Došlo také k neuváženému propouštění příslušníků policie, na jejichž př́ipravu bezpečnostní sbor investoval obrovské náklady (vyškolení, vystrojení, umožnění studia na vysokých školách).

Do podobné situace se dostal i Hasičský záchranný sbor České republiky, který v roce 2010 měl rozpočet ve výši 8,5 miliardy korun a v roce 2011 se snížil na 6,9 
miliardy korun. Projevilo se to v následujících letech prodloužením dojezdových časů a snížením profesionální úrovně při zásazích. Odešlo téměř 300 hasičů, byly téměř zrušeny investice a významně omezeny výdaje na provoz. Byl tím podstatně omezen rozvoj organizace. Přitom v roce 2011 hasiči zachránili majetek v hodnotě přes osm miliard korun. Vzhledem k tomu, že rozpočet se snižoval i v dalších letech celkově o jeden a půl miliardy korun, dostal se hasičský sbor do krizového stavu. Svědčil o tom fakt, že podobně jako u armády a policie $77 \%$ rozpočtu hasičủ tvořily mandatorní výdaje, př́ijmy přitom klesly o $7 \%$. Problémy byly i ve struktuře, z 9000 tisíc zaměstnanců jen 6000 bylo přímo v hasičských záchranných sborech.

Zpravodajské služby především znepokojovaly neustálé pokusy politiků je reformovat, většinou v rámci úspor je sjednotit, což se v průběhu druhé dekády podařilo, ale brzy se ukázalo, že takový krok je neefektivní a nebezpečný, takže se záhy rozdělily, aby o několik poté se opět začalo hovořit o sjednocení. Poněkud to připomínalo námět jedné politické strany ve volbách v roce 2010 spojit ministerstvo vnitra a ministerstvo obrany, aby posléze jeden z jejích politických představitelů osobně zjistil, že nestačí ani jedno. Po abdikaci mu nevadilo, aby získal parlamentní funkci, žádat o rozdělení výboru pro obranu a bezpečnost, což se mu podařilo.

Bezpečnostní systém se dostal na pokraj kolapsu před polovinou druhé dekády, kdy, k podobným nepokojům jako na Šluknovsku došlo i na Ostravsku, aby se nakonec rozširrilo po celých severních Čechách a severní Moravě a nakonec i do Prahy. Vláda na to reagovala operativním přemistováním policistů a po nezvládnutí situace i nasazením vojáků, což vyvolalo nespokojenost a vedlo k politické nestabilitě, která vedla k pádu vlády. Ta nová nakonec pro nedostatek prostředků musela přijmout progresivní daň, zdanit více podnikání velkých firem, zavést majetkovou daň a zdanit tzv. Tobinovou daní burzovní operace. Teprve tato opatření vedla k uklidnění situace.

\section{Závěr}

Druhá dekáda 21. století byla velmi neklidná. A to nejen pro doznívání finanční, ekonomické a sociální krize a důsledky dění v arabském světě, ale i stárnutím obyvatelstva, zvýšenou migrací a malou schopností zvládat korupci, kriminalitu a organizovaný zločin.

Krize eurozóny měla nejen evropský, ale i globální rozměr, eurozóna byla vedle USA nejvýznamnějším světovým ekonomickým aktérem, její kolaps by býval měl mimořádně závažné evropské, ale i globální ekonomické a bezpečnostní důsledky, a proto na jejím pádu nikdo neměl zájem. Nový faktorem nestability se staly středomořské hranici EU jako důsledek arabských vzpour. Tunisko, Libyi, Egypt, Sýrii a další arabské země provázely po dlouhá léta vleklé krize, negativně působil i neřešený izraelsko-arabský konflikt a neúspěch unijní politiky evropského sousedství.

V měnící se Evropě a v měnícím se světě se prohloubila závislost ČR na vývoji v EU a eurozóny a na vývoji světové ekonomiky a politiky. Pro omezené prostředky neměla ČR nikdy možnosti tento vývoj ovlivňovat a čelit samostatně novým výzvám v EU. Postavení země uškodilo ignorování této skutečnosti, což vytvářelo vážné problémy a rizika pro budoucí vývoj v ČR. Tuto skutečnost si dlouho neuvědomovala ani veřejnost.

Na druhé straně se ukončením iráckého a afghánského konfliktu Evropě podstatně ulevilo. To vytvořilo předpoklad pro strategické změny jak v Severoatlantické alianci, 
tak v Evropské unii. NATO se soustředilo na udržení atlantických vazeb a jaderné síly, na vytváření protiraketového štítu a na udržování rezerv vojenských jednotek pro možné zahraniční operace. Evropská unie svoji prioritu spatřovala v ochraně svého prostoru, zvláště schengenského, a to zvláště z východu a z jihu, což vedlo i k transformaci části vojenských jednotek v jednotky typu pohraniční stráže, druhým strategickým cílem bylo poskytovat humanitární pomoci v ohrožených oblastech. Společným strategickým cílem obou organizací poté bylo zabránit kybernetické válce.

Přesunutí těžiště amerického bezpečnostního zájmu do pacifického prostoru se vzájemné vztahy s evropskými zeměmi neoslabily. Spojené státy jen usilovaly o to, aby se evropské země více podílely na financování své obrany a zajištování bezpečnosti ve světě. Američané se nemohli od Evropy odpoutat už jen proto, že neměli ve světě spolehlivější partnery. Evropa pro ně představovala i jisté zápolí pro jejich strategické zájmy na Blízkém a Středním východě.

\section{Text byl zpracován v rámci výzkumného úkolu MSM 0021620841.}

Autor děkuje za cenné připomínky Felixi Černochovi, Luboši Dobrovskému, Janu Duchkovi, Pavlu Fričovi, Miloslavu Hadovi, Josefu Pavlasovi, Bohuslavu Pernicovi a Stanislavu Ševč́́kovi.

\section{Poznámka k textu:}

[1] Nassim Nicholas Taleb (nar. 1960 Amijún, Libanon) je libanonsko-americký esejista, odborník v oboru pravděpodobnosti a finanční matematiky. Bestseller amerického akademika a investičního poradce libanonského původu analyzuje fenomén „„̌erných labutí“, tj. nepředvídaných jevů a událostí s významným dopadem na život jedince nebo celé společnosti, jakým byl např. teroristický útok z 11. zář́ 2001, fenomenální úspěch společnosti Google či nedávná globální finanční a ekonomická krize. Autor - jeden z mála odborníků, kteří nástup krize předvídali - věří, že př̌ičinou naší nepřipravenosti na podobné zlomové události je především setrvačnost našeho myšlení v podobě př́ilišné důvěry ve statistiky a prognostiky, přehnaného kategorizování, hledání „logiky“ vývoje či soustřed’ování se na specifika tam, kde bychom měli přemýšlet spíše v obecných kontextech. Jeho kniha, vyzývající $\mathrm{k}$ tomu, abychom přehodnotili náš ustálený pohled na svět a přiznali si, jak málo o něm víme, patří dnes k nejdiskutovanějším pracím ve svém žánru, deníkem Times byla označena za jedno z nejvlivnějších děl posledních šedesáti let a díky autorovu širokému rozhledu, smyslu pro humor a zdravé provokativnosti je i velkým čtenářským zážitkem, http://www.kosmas.cz/knihy/162293/cerna-labut/.

\section{Použitá literatura a prameny:}

CORNISH, Edward. Futuring: The Exploration of the Future. [Futuring: Zkoumání budoucnosti]. USA: World Future Society, 2004, 313 s., ISBN 0-930242-61-0.

FRIČ, P.-VESELÝ, A. (ed.). Riziková budoucnost: devět scénár̆u vývoje české společnosti. Praha: Matfyzpress, 2010, 93 s. ISBN 978-80-7378-110-1. Autoři scénářů: M.Balabán, V. Benáček, P. Frič, J. Kloudová, M. Nekola, M. Nekolová, F. Ochrana, M. Potůček, A. Rašek.

HVÍŽĎALA, K.- RUPNIK, J. Př́liš brzy unavená demokracie. Praha: Portál, 2009, 280 s., ISBN 80-7367458-8.

LUPTÁK, L.- KALINIČ, L. Swarming - základní aspekty, vývoj a perspektivy využití konceptu. Vojenské rozhledy, 2012, roč. 21, č. 2, s. 66-75, ISSN 1210-3292.

POTƯČEK M. Poznávání budoucnosti jako výzva. Praha: Karolinum, 154 s. 2011, ISBN 978-80-246$1897-5$.

TALEB, N. N. Černá labut: Následky vysoce nepravděpodobných událostí. Praha: Paseka, 2011, 478 s. ISBN 978-80-7432-128-3. 